\title{
ACTION OF ACETYLCHOLINE ON THE PURKINJE FIBER STUDIED BY VOLTAGE CLAMP TECHNIQUE
}

\author{
Toyomi SAno, Yutaka IIDA AND Masayasu HiraOKA \\ Institute for Cardiovascular Diseases \\ Tokyo Medical and Dental University
}

In spite of the general belief that acetylcholine has no effect on the mammalian cardiac ventricle, several reports have appeared describing a slight effect on the action potential of the Purkinje fiber ${ }^{28)}$ and of the ventricular muscle fiber ${ }^{18}$ and its inotropic action on the ventricle in a high concentration $^{1,2,12,25,29)}$. The ionic hasis of acetylcholine effects on the atrium was examined to some extent by FOzZARD and SLEATOR ${ }^{11}$ by the current clamp method. Such being the state, the ionic basis of acetylcholine effects on the Purkinje fibers was studied by the voltage clamp method.

\section{METHOD}

Young calf hearts obtained from the slaughterhouse were brought to the laboratory in cool (about $4^{\circ} \mathrm{C}$ ) Tyrode solution. The $\mathrm{pH}$ of the Tyrode solution was set at 7.4 by adding an appropriate amount of $\mathrm{NaOH}$. Bundles of Purkinje fibers (diameter 0.3 to $0.5 \mathrm{~mm}$ ) were removed from the right ventricles. Two ligatures were set at a distance of 1 to $2 \mathrm{~mm}$ from each other by means of silk threads as proposed by DECK, KERN and TRAUTwEIN ${ }^{4}$. The preparations were kept in a Tyrode solution of $33^{\circ} \mathrm{C}$, saturated with a mixture of $95 \% \mathrm{O}_{2}$ and $5 \% \mathrm{CO}_{2}$. The Tyrode solution was changed to a sodium-free solution when necessary, which was prepared by replacing the $137 \mathrm{mM}$ $\mathrm{NaCl}$ of Tyrode solution with $137 \mathrm{mM}$ choline-chloride (choline-Tyrode solution) or 274 $\mathrm{mM}$ sucrose (sucrose-Tyrode solution). The composition of these solutions and the buffer followed Dudel, Peper and Trautweing) in the main.

Membrane voltage was clamped by a device consisting of an intracellular electrode which measures the membrane potential, a second intracellular electrode through which a current is fed into the fiber, and a feedback amplifier which supplies the correct amount of current in order to keep the membrane potential at a chosen level. Other details of the voltage clamp method and apparatus are the same as described by DECK, Kern and Trautwein ${ }^{4}$. Assuming that the Purkinje fiber bundle of several closely packed cells behave electrically like a single cell, its surface membrane was approximately determined, and these values were used to calculate the current densities (A/ $\mathrm{cm}^{2}$ ) of the feedback clamp current, as described by them.

Received for publication May 24, 1969

佐野豊美, 飯田 豊, 平岡昌和 


\section{RESULTS}

The control state

Compared with the results of our experiments with the rabbit and dog heart, the resting potential of some preparations of calf Purkinje fibers was often slightly smaller, being about $-60 \mathrm{mV}$. Preparations which showed a resting potential less than this value were discarded. Since other preparations of calf Purkinje fibers showed a resting potential as large as about $-90 \mathrm{mV}$, this relatively small resting potential was probably due to occasional unfavorable conditions in the slaughterhouse.

The current voltage relation in the control state was similar to that reported by DECK and TRAUTWEIN ${ }^{5}$. When the membrane was depolarized by clamping from $-80 \mathrm{mV}$ to a constant level for $300 \mathrm{msec}$ in a stepwise fashion up to $-10 \mathrm{mV}$ the curves showed generally the $\mathrm{S}$ form, and the

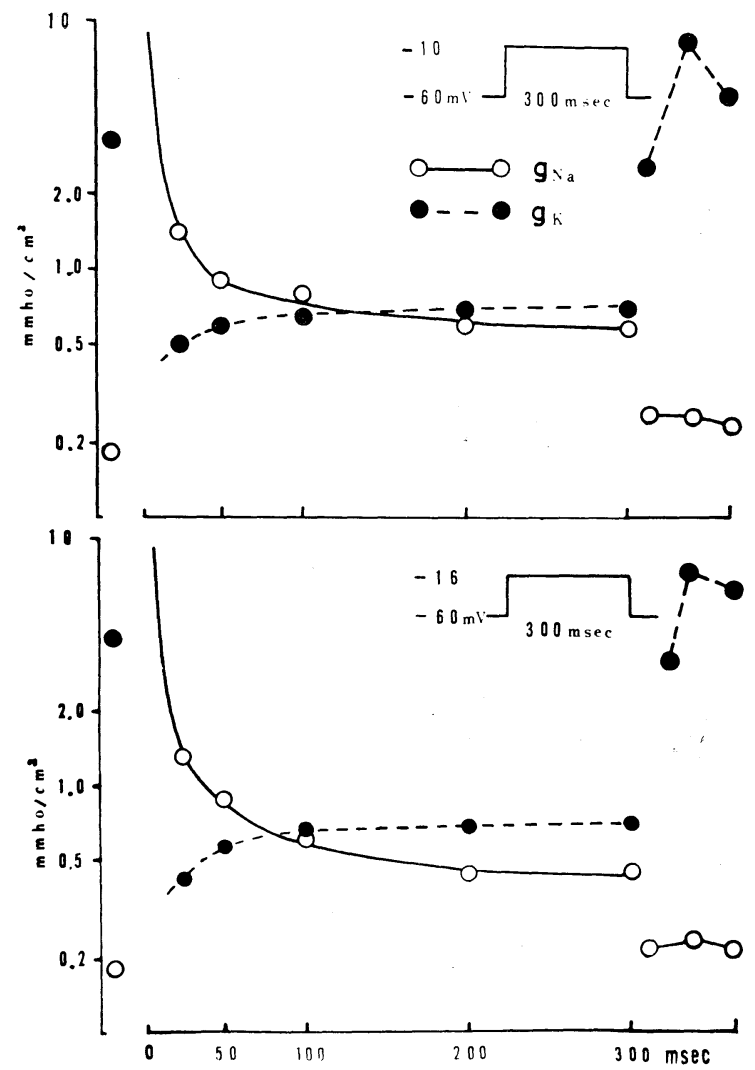

FIG. 1. Voltage-dependent and time-dependent changes of the chord conductance of a calf Purkinje fiber in the control state in depolarization to $-10 \mathrm{mV}$ (upper tracings) and to $-16 \mathrm{mV}$ (lower tracings). 
current at $25 \mathrm{msec}$ after the onset of the clamp was negative at about -20 $\mathrm{mV}$ and showed a negative slope between $-45 \mathrm{mV}$ to $-20 \mathrm{mV}$.

Assuming that the ionic current of the cell membrane consists chiefly of $\mathrm{Na}^{+}$and $\mathrm{K}^{+}$, as HodgKin and HuxLEY ${ }^{15,16)}$ did on the giant axon of Loligo, and that the potassium current can be measured when the $\mathrm{NaCl}$ of Tyrode solution was replaced by sucrose, the chord conductances for sodium $\left(\mathrm{g}_{\mathrm{Na}}\right)$ and potassium $\left(\mathrm{g}_{\mathrm{K}}\right)$ were calculated. When the current voltage relation was examined under normal conditions only, the $\mathrm{NaCl}$ of Tyrode solution was replaced by cholinechloride in some experiments, but no conspicuous difference was observed from the results by replacement with sucrose. The time changes of $g_{\mathrm{Na}}$ and $\mathrm{g}_{\mathrm{K}}$ when the voltage was clamped at $-10 \mathrm{mV}$ (the upper figure) and at $-16 \mathrm{mV}$ (the lower figure), from the resting potential level of $-60 \mathrm{mV}$ are shown in FIG. 1 . The $\mathrm{g}_{\mathrm{Na}}$, which increased markedly at the beginning of depolarization, decreased rapidly until about $50 \mathrm{msec}$ after the onset of depolarization and then slowly until $300 \mathrm{msec}$, which was the total duration of the depolarizing step. The $g_{K}$, which showed a marked decrease

A

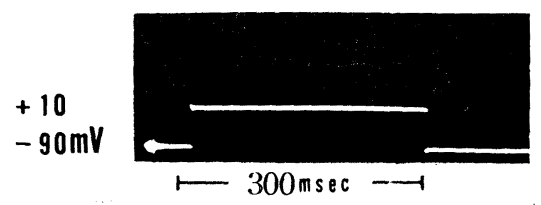

B

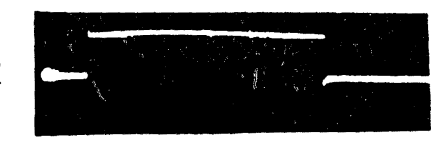

4
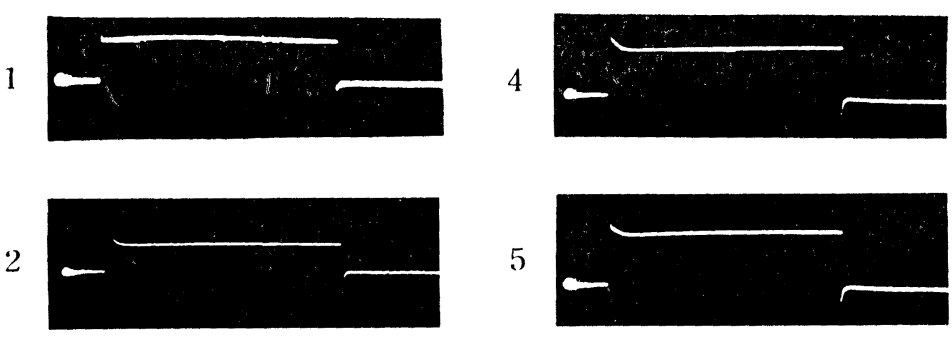

5
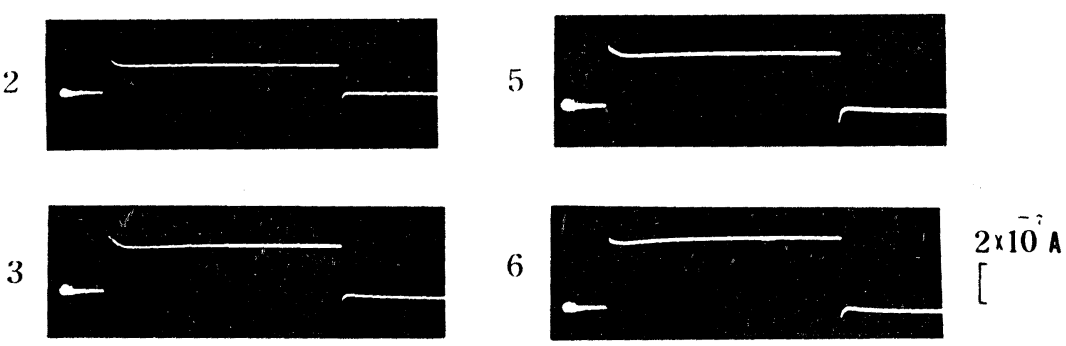

FIG. 2. An example of change of membrane current during depolarization after addition of acetylcholine to Tyrode solution. Resting and clamp potentials of the preparation and duration of depolarization are indicated in Fig. A. The membrane current is shown in FIG. B as follows. B1: in the control state; B2: 1.5 minutes after addition of acetylcholine to a concentration of $10^{-5} \mathrm{~g} / \mathrm{ml} ; \mathrm{B} 3$ : after 2.5 minutes; B4: after 3 minutes and immediately after further addition of acetylcholine to concentration of $10^{-3} \mathrm{~g} / \mathrm{ml}$; B5: after 4 minutes; B6: after 6.5 minutes. 
at the beginning of depolarization, showed a fairly rapid increase until 100 msec after the onset of depolarization and a gradual increase thereafter.

\section{Effects of acetylcholine}

Acetylcholine was dropped into the solution to obtain the desired final concentration.

Up to the final concentration of $10^{-6} \mathrm{~g} / \mathrm{ml}$, no significant change in the ionic currents of Purkinje fibers was noticed, compared with the control. In a concentration higher than $10^{-5} \mathrm{~g} / \mathrm{ml}$ there were some changes which varied with time. Namely, the measured current decreased initially and increased later. In the experiment shown in FIG. 2 the voltage was clamped at $+10 \mathrm{mV}$ from the resting potential of $-90 \mathrm{mV}$ and acetylcholine was added to obtain

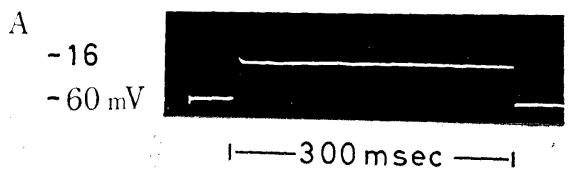

B
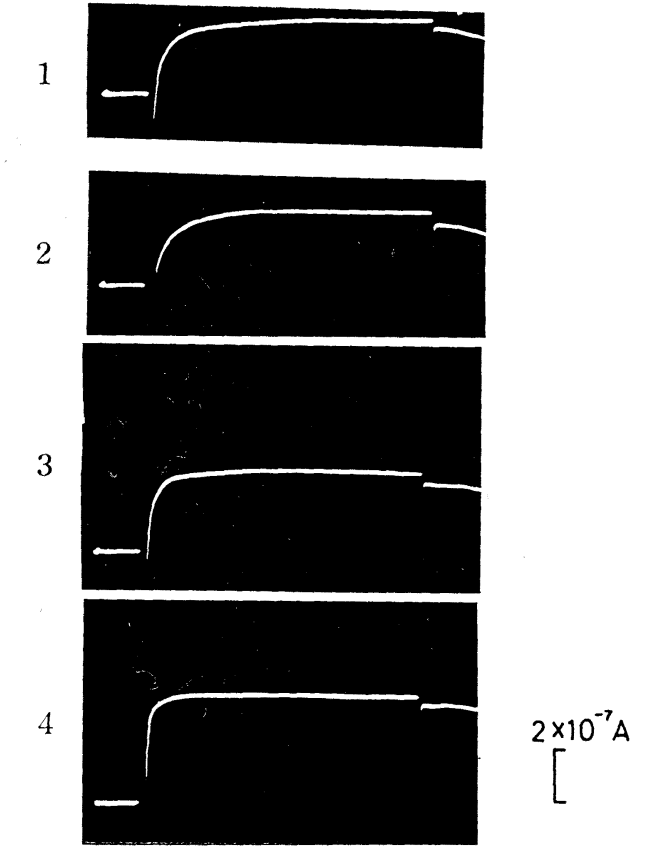

FIG. 3. Another example of change of membrane current during depolarization after addition of acetylcholine to Tyrode solution to a concentration of $10^{-4} \mathrm{~g} / \mathrm{ml}$. Fig. A is the same as in Fig. 2A. The membrane current is shown in FIG. B as follows. B1: in the control state; B2: 1.5 minutes after addition of acetylcholine to a concentration of $10^{-4} \mathrm{~g} / \mathrm{ml} ; \mathrm{B} 3$ : after 2.5 minutes; $\mathrm{B} 4$ : after 5 minutes. 
a final concentration of $10^{-5} \mathrm{~g} / \mathrm{ml}$. Immediately after its addition there was a decrease of positive outward current. It recovered and increased gradually, exceeding the control value in about three minutes. In this experiment this increase became more marked when acetylcholine was added further to obtain a final concentration of $10^{-3} \mathrm{~g} / \mathrm{ml}$. The same initial decrease and later increase of the positive outward current are noticed in FIG. 3, in which the initial inward current is seen. Acetylcholine was added to a concentration of $10^{-4} \mathrm{~g} / \mathrm{ml}$.

Effects of acetylcholine were examined when the $\mathrm{NaCl}$ of Tyrode solution was replaced by sucrose. It was found that the increase of the positive outward current due to acetylcholine was more marked than in the Tyrode

A

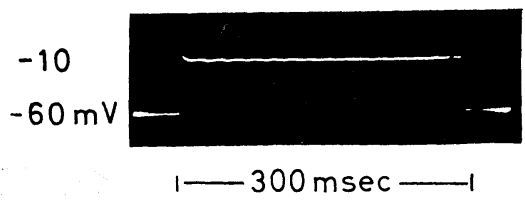

B
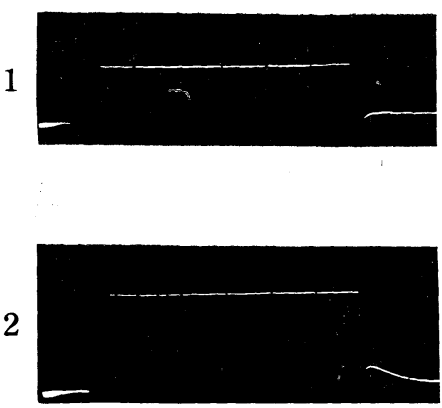

3
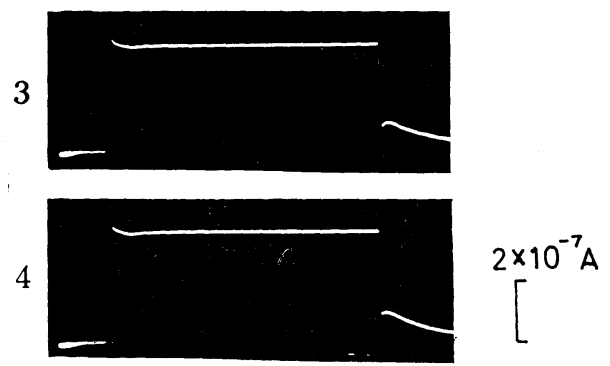

FIG. 4. Change of membrane current during depolarization after addition of acetylcholine to sucrose-Tyrode solution to a concentration of $10^{-4} \mathrm{~g} /$ m1. Fig. A is the same as in Fig. 2A. The membrane current is shown in FIG. $\mathrm{B}$ as follows. $\mathrm{B} 1:$ in the control state; $\mathrm{B} 2: 1.5$ minutes after addition of acetylcholine to a concentration of $10^{-4} \mathrm{~g} / \mathrm{ml}$; B3 : after 3 minutes; B4: after 5 minutes. 
solution (FIG. 4). This indicates that the increase of potassium current was induced by acetylcholine.

The $g_{\mathrm{Na}}$ and the $\mathrm{g}_{\mathrm{K}}$ were calculated at each voltage and time as shown in FIG. 5. In this calculation the sodium current change $\Delta \mathrm{I}_{\mathrm{Na}}$ was obtained by substracting the potassium current change $\Delta \mathrm{I}_{\mathrm{K}}$ from the total current change $\Delta \mathrm{I}_{\mathrm{m}}$. This $\Delta \mathrm{I}_{\mathrm{m}}$ was obtained as the difference between the current, when acetylcholine was added (to $10^{-4} \mathrm{~g} / \mathrm{ml}$ in FIG.. 5) to the normal Tyrode solution, and that before its addition. The $\Delta \mathrm{I}_{\mathrm{K}}$ was obtained as the difference between the current, when acetylcholine was added to the Na-free solution which was obtained by replacing the $\mathrm{NaCl}$ of Tyrode solution by sucrose, and that before its addition. A change of the $\mathrm{g}_{\mathrm{Na}}$ was noticed in addition

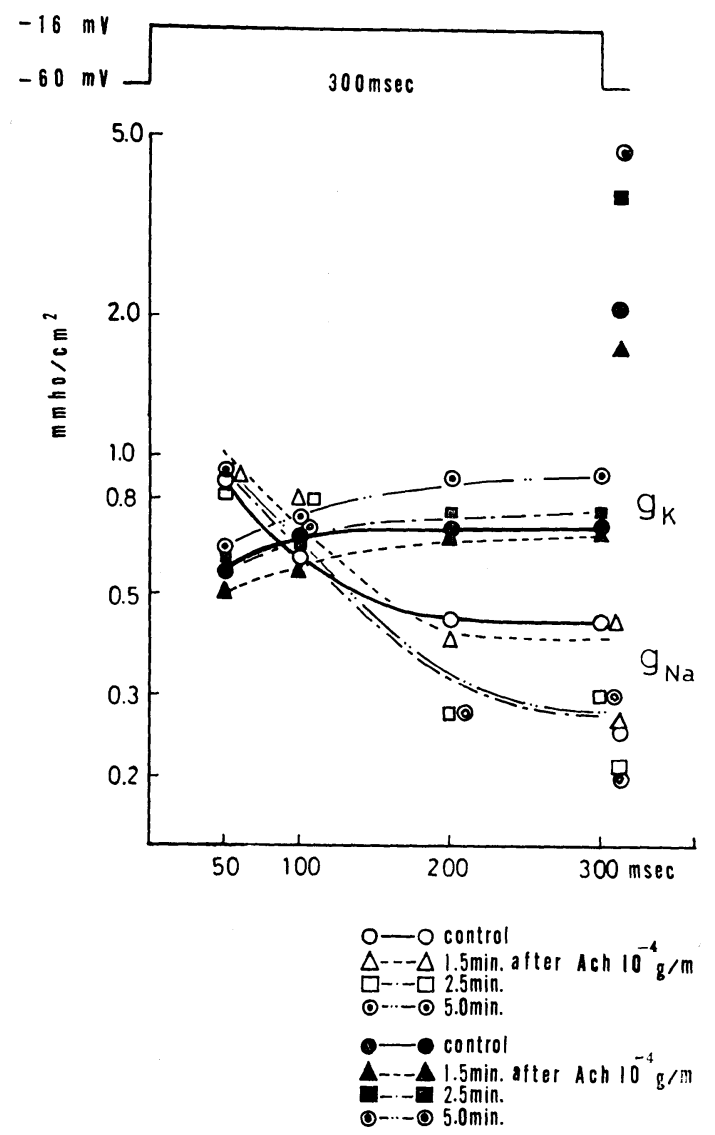

FIG. 5. Changes of the chord conductance in depolarization by addition of acetylcholine to a concentration of $10^{-4} \mathrm{~g} / \mathrm{ml}$. Abscissa shows the time after the onset of depolarization. Ordinate shows the chord conductance. Resting and clamp potentials of the preparation are indicated on the potential schema. 
to the $g_{K}$ change, as FOzZARD and SLEATOR ${ }^{11)}$ described with acetylcholine effect on the ionic current of the atrial muscle fibers, although acetylcholine concentration was much higher in this experiment. Compared with the control state, the $g_{K}$ decreased soon after the addition of acetylcholine throughout the whole duration of depolarization, but increased later. The $\mathrm{g}_{\mathrm{Na}}$ increased in the first phase of depolarization up to about $150 \mathrm{msec}$, but beyond this phase it decreased progressively. Namely, sodium inactivation became more rapid than in the control state.

\section{DISCUSSION}

Our result on the normal control state showed some difference from that of a similar experiment by DECK and TRAUTWEIN ${ }^{5,6)}$. The decrease of $g_{\mathrm{Na}}$ was more rapid in our result than in their result, although it must be admitted that the inactivation of $\mathrm{g}_{\mathrm{Na}}$ was slow and incomplete, as they described. The $\mathrm{g}_{\mathrm{K}}$ decreased markedly immediately after depolarization and increased rapidly later up to about $100 \mathrm{msec}$ and slowly thereafter in our result, while the $g_{k}$ continued to decrease after depolarization in their result. Since the delayed increase of the $g_{K}$ was slight, our result cannot be very definite, but it is rather closer to the results by HALL, HUTTER and NOBLE ${ }^{14)}$ and MCALLISTER and NOBLE ${ }^{23)}$.

According to our result the repolarization phases of the action potential of Purkinje fibers can be explained as follows: there is a time-dependent change of the $g_{K}$ early in the phase, especially up to $100 \mathrm{msec}$. As shown by the conductance at $-10 \mathrm{mV}$ and $-16 \mathrm{mV}$ in FIG. 1 , the $\mathrm{g}_{\mathrm{Na}}$ and $\mathrm{g}_{\mathrm{K}}$ show a voltage-dependent change, inducing a change in the time at which the $\mathrm{g}_{\mathrm{Na}}$ and $\mathrm{g}_{\mathrm{K}}$ cross each other. The plateau of the action potential is formed because the decrease of $g_{N a}$ is relatively smaller and the increase of $g_{K}$ is initially not marked. But the $\mathrm{g}_{\mathrm{Na}}$ shows a time-dependent decrease, becoming especially small beyond $100 \mathrm{msec}$ of depolarization, and the $\mathrm{g}_{\mathrm{K}}$ shows a gradual increase, which causes an outflow of potassium ions from the cell and a decrease of the membrane potential. This induces a marked decrease of $\mathrm{g}_{\mathrm{Na}}$ and a less marked increase of $g_{K}$. Eventually the $g_{N a}$ becomes smaller than $g_{K}$, and phase 3 of the action potential is produced.

The above-mentioned $\mathrm{g}_{\mathrm{Na}}$ and $\mathrm{g}_{\mathrm{K}}$ were obtained on the conventional assumption that the ionic current of the cell membrane consists chiefly of $\mathrm{Na}^{+}$ and $\mathrm{K}^{+}$and the potassium current can be measured when the $\mathrm{NaCl}$ of Tyrode solution was replaced by sucrose, glucose or choline chloride, but recently several authors have more or less cast doubt on the application of this assumption to Purkinje fibers. GLITSCH and $\mathrm{HAAS}^{13)}$ observed that the $\mathrm{K}$ flux evidently changed when extracellular $\mathrm{Na}$ was replaced by choline. DECK and TRAUTWEIN $^{5)}$ showed that, in the case of Purkinje fibers, replacement of 
sodium by choline or glucose virtually abolishes the outward current which occurs immediately following depolarizing clamps. Employing $\mathrm{K}^{42}$ efflux measurements under voltage clamp conditions, HAAS and $\mathrm{KERN}^{13)}$ also found a larger value of the $K$ net flux in the range of depolarization than that determined by electrical methods, although they noticed that both methods in general yielded qualitatively similar results.

Further studies by several authors have revealed that ionic currents for chloride and calcium and other unknown negative non-sodium currents cannot be ignored in the electrical activity of Purkinje fibers. But there are still many unknown details and serious disagreements. FOzZARD and SLEATOR ${ }^{11}$ estimated the chloride conductance to be, on an average, $12 \%$ of the $\mathrm{g}_{\mathrm{K}}$ of the resting membrane. DUDEL, PEPER, RÜDEL and TRAuTweIN ${ }^{8)}$ found that the chloride current in relation to the relative contribution to the net current increased from $20 \%$ at rest to $50 \%$ or more at positive potentials in the steady state and that its peak was delayed by about $20 \mathrm{msec}$ from the start of the depolarization, being inactivated with a time constant of $50 \mathrm{msec}$. REUTER ${ }^{26,27)}$ found that a slow inward current was carried by calcium ions, but DuDEL, PePer and TRAUTWEIN ${ }^{9}$ found no appreciable calcium current to flow in the range of membrane potentials covered by the action potential. DUDEL, PEPER, RÜDEL and TRAUTWEIN, ${ }^{713}$ proposed the presence of a " negative non-sodium " current other than the calcium current, the carrier of which was unknown.

With this information as reference, our results mentioned above should be reconsidered. As for the problem described at the beginning of the DIScussION, further reports have appeared after DECK and TRAUTWEIN ${ }^{5,6}$. While DECK and TRAUTWEIN ${ }^{5)}$ and MCALLISTER and NOBLE ${ }^{23)}$ proposed a slow or an incomplete inactivation of $\mathrm{g}_{\mathrm{Na}}$, and REUTER ${ }^{27)}$ also endorsed it, DUdEL, PEPER, RÜDEL and TRAUTWEIN ${ }^{\text {() }}$ found a rapid and almost complete inactivation of $\mathrm{g}_{\mathrm{Na}}$ and no component of delayed rectification of $\mathrm{g}_{\mathrm{K}}$ in contrast to VASALLE ${ }^{32}$ and MCALLISTER and NOBLE ${ }^{23,24)}$. According to our results, even in the experiments, in which the $g_{K}$ was obtained by replacement of $\mathrm{NaCl}$ of the normal Tyrode solution by choline-chloride, the $\mathrm{g}_{\mathrm{K}}$ showed a delayed increase after depolarization. In this case the chloride current component may be included in the $\mathrm{g}_{\mathrm{K}}$ at the beginning of the depolarization. By substracting this component the result would show more markedly that the real potassium conductance increases with delay. Since MCAllister and NoBlE ${ }^{23)}$ and others ${ }^{5,13)}$ showed that the delayed increase in $g_{K}$ after depolarization is depressed in the sodium free solution, the real potassium conductance would be larger than our $\mathrm{g}_{\mathrm{K}}$.

Further accurate revision of the above-mentioned $g_{N a}$ and $g_{K}$ seems to be impossible in view of the lack of agreement at present. For instance, our finding of an acetylcholine effect described as an increase of the $\mathrm{g}_{\mathrm{Na}}$ especially in the early phase of depolarization might be related to an increase of calcium 
current instead, but no reliable data seem to be present to permit a revision on the ionic currents other than sodium and potassium under the influence of acetylcholine or any other drugs. For a while they must be regarded as an inward and outward conductance obtained by the method described.

Most studies admitted that acetylcholine has little effect on the electrical activity of the cardiac ventricle. But earlier studies of LUEKEN and SCHÜTZ ${ }^{22}$ with suction electrodes showed that $1: 5,000$ acetylcholine did speed repolarization in the frog ventricle and HoFFMAN ${ }^{19)}$ saw a similar effect in records of transmembrane potential from single fibers of the frog ventricle. As for the mammalian ventricle HoFFMAN and SUCKLING ${ }^{18)}$ noticed, with the papillary muscles of the dog ventricle, no change of the action potential and the resting potential in a concentration up to $5.5 \times 10^{-4} \mathrm{M}$ and a very slight increase in the slope of phase 2 and a corresponding decrease in the slope of phase 3 in a very high concentration $\left(11 \times 10^{-2} \mathrm{M}\right)$. SCHMIDT ${ }^{28)}$ showed that a high concentration of $10^{-4} \mathrm{~g} / \mathrm{ml}$ of acetylcholine shorten the action potential of Purkinje fibers by about 10\%. SUZUKI, SATO, IIDA, HiraOKA and SANO ${ }^{30}$ noticed in the rabbit papillary muscle fibers that acetylcholine in a concentration of $10^{-3} \mathrm{~g} / \mathrm{ml}$ shortened the duration of the action potential first with an increase in the slope of phase 3 and prolonged it later with the prolongation of phase 3. They ${ }^{30)}$ also observed that in the dog Purkinje fiber acetylcholine in $10^{-4} \mathrm{~g} / \mathrm{ml}$ prolonged slightly the duration of the action potential with the prolongation of phase 3 .

In spite of the scantiness of the reports in which were noticed changes of electrical activity of the Purkinje fibers or ventricular muscle fibers, the number of reports which described either the positive ${ }^{2}{ }^{3,10,17,21,25)}$, negative or biphasic ${ }^{10,20)}$ inotropic effect of acetylcholine on the ventricle is increasing, although much controversy still exists. For instance, Buccino, SonNENBLICK, COOPER and BRAUNWALD ${ }^{2)}$ described its positive inotropic effect in a concentration of $10^{-5}$ to $3 \times 10^{-4} \mathrm{~g} / \mathrm{ml}$ and frequently a small negative effect in a concentration of $10^{-9}$ to $10^{-7} \mathrm{~g} / \mathrm{ml}$ on the cat papillary muscle. SCHMIDT ${ }^{28>}$ found an initial negative inotropic action followed by a positive inotropic action by $10^{-5}$ to $10^{-4} \mathrm{~g} / \mathrm{ml}$ of acetylcholine without noticing any change of resting potential and the action potential. SUZUKI, SATO, IIDA, HIRAOKA and $\mathrm{SANO}^{30}$ noticed a similar biphasic inotropic action, but found some correlation with the above-mentioned changes of the action potential in a higher concentration. In this study, although a biphasic inotropic action was noticed up to $10^{-5} \mathrm{~g} / \mathrm{ml}$, no distinct change of the action potential could be noticed at this lower concentration.

In the present study, no significant change in the ionic currents of Purkinje fibers was noticed up to the final concentration of $10^{-6} \mathrm{~g} / \mathrm{ml}$ of acetylcholine, but some changes were noticed, more or less frequently, in a concentration higher than $10^{-5} \mathrm{~g} / \mathrm{ml}$. Our result showing an initial decrease of 
current and a later increase by acetylcholine with Purkinje fibers seems to have some relation with that of SUZUKI, SATO, IIDA, HIRAOKA and SANO ${ }^{30}$, which showed that the isotonic contraction of isolated rabbit papillary muscles showed a slight decrease soon after the addition of acetylcholine and an increase thereafter. Although the electrical phenomenon of Purkinje fibers should not be directly correlated with the mechanical action of ventricular muscle fibers, the lack of changes of the action potential or resting potential of Purkinje fibers and ventricular muscle fibers in a concentration of about $10^{-5} \mathrm{~g} / \mathrm{ml}$ may be merely an outward appearance. Otherwise the relatively larger ionic currents might be due to a slightly depolarized resting state occasionally found in this technic.

At this time when there are marked differences of opinions on the calcium current, it seems to be too much speculation to consider the relation between these obtained values of assumed $g_{\mathrm{Na}}$ and $\mathrm{g}_{\mathrm{K}}$ with such controversial findings of inotropic action of acetylcholine on the ventricle, especially because our findings were obtained with Purkinje fibers and not with the ventricular muscle fibers.

\section{SUMMARY}

Ionic currents in excitation and effects of acetylcholine on them were examined with isolated young calf Purkinje fibers by means of the voltage clamp technique. It was found that in the control state the $\mathrm{g}_{\mathrm{Na}}$, which increased markedly at the beginning of depolarization, decreased rapidly until about $50 \mathrm{msec}$ and thereafter slowly. The $\mathrm{g}_{\mathrm{K}}$, which showed a marked decrease at the beginning of depolarization, showed a fairly rapid increase until $100 \mathrm{msec}$ and a gradual increase thereafter.

Acetylcholine showed no significant effects on the ionic current up to the concentration of $10^{-6} \mathrm{~g} / \mathrm{ml}$. In a concentration higher than $10^{-5} \mathrm{~g} / \mathrm{ml}$ the $\mathrm{g}_{\mathrm{K}}$ decreased soon after the addition of acetylcholine, but increased later. The $\mathrm{g}_{\mathrm{Na}}$ increased during the first phase of depolarization up to about $150 \mathrm{msec}$, but beyond this phase it decreased progressively.

\section{REFERENCES}

1) Blumethal, M.R., Wang, H. H., Markee, S. and Wang, S.C. Effects of acetylcholine on the heart. Am. J. Physiol. $214:$ 1280-1287, 1968.

2) Buccino, R. A., Sonnenblick, E. H., Cooper, T. and Braunwald, E. Direct positive inotropic effect of acetylcholine on myocardium; evidence for multiple cholinergic receptors in the heart. Circulation Res. 19: 1097-1108, 1966.

3) Burn, J.H. AND RAND, M. J. Acetylcholine in adrenergic transmission. Ann. Rev. Pharmacol. 5 : 163-182, 1965.

4) Deck, K. A., Kern, R. and Trautwein, W. Voltage clamp technique in mam- 
malian cardiac fibers. Pflügers Arch. ges. Physiol. 280: 50-62, 1964.

5) Deck, K. A. And Trautwein, W. Ionic currents in cardiac excitation. Pfiugers Arch. ges. Physiol. $280: 63-80,1964$.

6) Deck, K. A. And Trautwein, W. Voltage clamp in heart cells. In 'Electrophysiology of the Heart', edited by TACCARDi B. and MARChetti, G., Pergamon Press, Oxford, 1965.

7) Dudel, J., Peper, K., Rüdel, R. And Trautwein, W. Excitatory membrane current in heart muscle (Purkinje fibers). Pfiugers Arch. ges. Physiol. 292: 255273, 1966.

8) Dudel, J., Peper, K., Rüdel, R., and Trautwein, W. The dynamic chloride component of membrane current in Purkinje fibers. Pfiugers Arch. ges. Physiol. 295 : 197-212, 1967.

9) Dudel, J., Peper, K. and Trautwein, W. The contribution of Cat+ ions to the current voltage relation in cardiac muscle (Purkinje fibers). Pfiugers Arch. ges. Physiol. 288 : 262-281, 1966.

10) FERry, C. B. Cholinergic link hypothesis in adrenergic neuroeffector transmisson. Physiol. Rev. 46:420-456, 1966.

11) Fozzard, H. E. ANd Sleator, W. Membrane ionic conductances during rest and activity in guinea pig atrial muscle. Am. J. Physiol. 212: 945-952, 1967.

12) Friedman, W. F., Buccino, R. A., Sonnenblick, E. H. and Braunwald, E. Effect of frequency of contraction and ionic environment on the responses of heart muscle to acetylcholine. Circulation Res. 21 : 573-582, 1967.

13) HaAs, H. G. And Kern, R. Potassium fluxes in Purkinje fibers as a function of membrane potential. In 'Electrophysiology and Ultrastructure of the Heart'. edited by Sano, T., Mizuhira, V. and Matsuda, K., Grune \& Stratton, New York, 65-75, 1967.

14) Hall, A. E., Hutter, O. F. And Noble, D. Current-voltage relations of Purkinje fibers in sodium-deficient solutions. J. Physiol. $166: 225-240,1963$.

15) Hodgkin, A. L. And Huxley, A.F. Currents carried by sodium and potassium ions through the membrane of the giant axon of Loligo. J. Physiol. 116: 449-472, 1952.

16) Hodgkin, A. L. And Huxley, A.F. The components of membrane conductance in the giant axon of Loligo. J. Physiol. 116:473-496, 1952.

17) Hoffmann, F., Hoffmann, E. J., Middleton, S. and Talesnik, J. The stimulating effect of acetylcholine on the mammalian heart and the liberation of an epinephrine-like substance by the isolated heart. Am. J. Physiol. 144: 189, 1945.

18) Hoffman, B. F. ANd Suckling, E. E. Cardiac cellular pytentials : effect of vagal stimulation and acetylcholine. Am. J. Physiol. 173: 312-320, 1953.

19) Hoffman, B. F. And CRanefield, P. F. Electrophysiology of the Heart. McGrawHill, New York, p. 87, 1960.

20) Hollenberg, M., Carriere, S. and Barger, A. C. Biphasic action of acetylcholine on ventricular myocardium. Circulation Res. 16:527-536, 1965.

21) Lee, W.C. And Shideman, F.E. Mechanism of the positive inotropic response to certain ganglionic stimulants. J. Parmacol. Exptl. Therap. 126:239-249, 1959.

22) Lueken, B. And Schütz, E. Die relative Refraktärphase des Herzens, 3. Mitteilung: Reversibilität und Antagonismus, Z. Biol., 99: 186-197, 1938.

23) Mcallister, R.E. And Noble, D. The time and voltage dependence of the slow outward current in cardiac Purkinje fibers. J. Physiol. 186 : 632-662, 1966.

24) Mcallister, R.E. ANd Noble, D. The effect of subthreshold potentials on the membrane current in cardiac Purkinje fibers. J. Physiol. $190: 381-387,1967$.

25) Middleton, S., Oberti, C., Prager, R. and Middleton, H. H. Stimulating 
effect of acetylcholine on the papillary myocardium. Acta Physiol. 6: 82-89, 1956.

26) Reuter, H. The dependence of slow inward current in Purkinje fibers on the extracellular calcium-concentration. J. Physiol. 192: 479-492, 1967.

27) Reuter, H. Slow inactivation of currents in cardiac Purkinje fibres. J. Physiol. 197 : 233-253, 1968.

28) Schmidt, R. F. Über die Acetylcholin-empfindichkeit verschiedener Herzabschnitte, Arch. expt. Pathol. Pharmakol. Naunyn-Schmiedeberg's 233 : 531-540, 1958.

29) Schreiner, G. L., Berglund, E., Brost, H. G. And Monroe, R. G. Effect of vagus stimulation and acetylcholine on myocardial contractility, $\mathrm{O}_{2}$ consumption, and coronary flow in dogs. Circulation Res. 5: 562-567, 1957.

30) Suzuki, F., Sato, S., Iida, Y., Hiraoka, M. And Sano, T. Action of acetylcholine to the ventricle. J. Physiol. Society Japan. 31:431-432 (Japanese abstract) 1969.

31) Trautwein, W., Dudel, J. and Peper, K. Stationary S-shaped current voltage relation and hysteresis in heart muscle fibers. Excitatory phenomena in $\mathrm{Na}^{+}$-free bathing solutions. J. cell. comp. Physiol. 66, Supp1, 2: 79-90, 1965.

32) Vassalle, M. Analysis of cardiac pacemaker potential using a voltage clamp'technique. Am. J. Physiol. 210: 1335-1341, 1966. 